\title{
HIGHER EDUCATION CURRICULUM DEVELOPMENT STUDY : THE CONSEPT OF LINK \& MATCH WITH BUSINESS
}

\author{
Suyitno \\ PPs STIE Indonesia \\ (drsuyitno@yahoo.co.id.)
}

\begin{abstract}
High unemployment is not caused by absorption of college graduates in the job market. Gaps between the labor force with the world of work, due to link and match synchronization between the education system with the business. The role of universities should be able to bridge that gap by developing a competency-based curriculum, in order top reduce quality graduates or job seekers can meet the required qualifications and requirements of the business world. Link and match concept is realized through the social and labor approaches. While development in the college curriculum through approaches (1) academic, (2) life skills, (3) competency-based curriculum, (4) broad-based curriculum.
\end{abstract}

Keywords: universities, curriculum, link and match, job market.

\section{INTRODUCTION}

It is time the world of education, especially higher education look in the mirror and reflect on what is the flyer for the learners. Actually, between the world of education and the world of work are sustainable relationship process. Education world and the world of work as upstream as downstream. This process should go hand in hand so that what is taught in the education useful in the world of work. Instead the world of work can contribute to and feedback on education.

Muhaimin Iskandar said today in Indonesia is still a gap between the labor force and the labor market, because of the paucity of synchronization link and match the education system and the world of work. Also stated that it was time for college, as the culmination of the educational system to change the paradigm and orientation, so that the institution was only oriented to the implementation of teaching and research should lead also to the efforts to prepare graduates to enter the workforce. Therefore, the role of higher education is expected bridging the gap between the world of work and education (www.dpp.pbk.or.id). Other expectations are their innovations in higher education in the next few years more and more directed to the development of thinking skills at a higher level. In addition it must be ascertained what the college and what the world needs work, so the link and match can be immediately implemented by trying to match the educational curriculum and the 
labor market (http://www.indopos.co.id). Looking ahead, the employment sought is integrated between universities, central government, local government, businesses, and communities (http://edukasi.kompasiana.com/2011)

Government seeks to synergize the national education system with the system of employment in developing competency-based curriculum in accordance with the needs of business and job market. This synergy, is expected to produce quality graduates or job seekers to meet the qualifications and requirements needed by the business world or for entrepreneurship independently (www.dpp.pbk.or.id).

College curriculum was time-based job market or industry, as increasingly stringent global competition requires Indonesia to develop human resources significantly beginning of graduate. Competency is improvement that should be owned college graduates, namely to think critically and creatively, make decisions, solve problems and fast to learn. Some countries have been very focused on the development of high-level academic skills by performing various universities curriculum high improvement. United States of America has been very focused on the development of thinking skills that device (http://edukasi.kompasiana.com/2011),

Lyra in Farihin (2011) found that due to a mismatch between the college curriculum with the needs of the business, now many companies are recruiting fresh graduates do not match the requirements of the current student academic of company. Achievment mostly not directly proportional to work performance, consequently the time of entry The world of work they should get training first. This is a burden for companies, since companies often have to conduct continuous training for fresh graduates through the graduate trainee program and management trainee to provide readiness for new graduates working in the corporate world.

Anshori (2011) further highlights the percentage of the number of unemployed graduates of higher than the percentage of high school graduates lower levels of education. Meanwhile, according to the official version, there are nine million openly unemployed, fourteen percent of whom are alumni of similar education diploma and bachelor similar seventeen percent (http://edukasi.kompasiana.com/2012). Under these conditions it is assumed that the increase in the unemployment rate caused by the failure of the education system, it is necessary to approach certain in education and the concept of link and match needs to be revived in the education system.

Does not match its universities with the business world is not a good climate. On one side the business world requires a workforce that reliably and applicable in the field, but on the other hand are abundant college graduates had not even get a job with the appropriate field department.

To overcome this condition Lyra in Farihin (2011) says that the student after completing his college education is expected to be an apprentice to not only gain experience, but also have obtained a job simulation that gives better equipped to face the world of work. In addition, the necessary cooperation between universities and the business world, so that each benefit and mutually beneficial relationship, so that one day the business world can accept graduates fresh graduates who are ready to work. So that graduates can be absorbed labor 
market, must be addressed by universities to develop competency-based curriculum, so the link and match with the corporate world.

\section{HIGHER EDUCATION}

Higher education is implemented in Universities. Higher education is a vehicle experts who are expected to develop knowledge and contributing to the development. As a systematic effort to improve the quality of human resources, the Ministry of National Education has set four key policy in the field of education, namely (1) equity and opportunity; (2) the relevance of education to development; (3) the quality of education; and (4) the efficiency of education. Especially for college would be an advantage to discuss the relevance of education to development in the implementation steps are known as the relevance and proportionality (link and match).

The purpose of higher education programs are: (1) to reform the system of higher education; (2) improve the quality and relevance of higher education to the world of work; and (3) improving equitable opportunity to obtain higher education, particularly for outstanding students who come from poor families.

One of the strategic issues in the development of higher education is the need to increase the relevance of higher education to the needs of develop of higher education. Both graduates and science and technology product that it generates, is now considered not entirely able to play a role in meeting the needs of development in the broadest sense. it is translated by Dirman (tt) as the paradigm of education (education paradigm), according to the development of cultural life (living culture), and the advancement of science and technology (science technology). Paradigm it enters every level of education from primary to university level, and various programs offered to achieve equality graduates (output) with the world of work, so as to achieve relevance and proportionality (link and match).

\section{CONCEPT LINK AND MATCH}

Concepts Link and Match between educational institutions and the world of work is considered ideal, that there was a relationship between labor supply users, so that the reciprocal relationship making colleges can develop curricula according to the work (Soemarso in Anshori, 2011. For example apprenticeship programs that are now emerging, namely to create a cooperation agreement between the universities with the business world. Before student finish of studying at Universities, businesses prepare you for the readiness of students enter the business world without difficulty.

Ideally (Anshori, 2011) there are three components that must move simultaneously to the success of Link and Match program, the university, the world of work (company) and the government. The Role of Higher Education is mandatory and essential requirement, one of them to carry out research into the working world to know what is most needed competence and most of the required workforce. Furthermore Universities must establish relationships (relationships) and creates a link with the world of work (company) to be willing to be a learning arena of work (internships) for students who will graduate. With direct internship (on the spot) to the world of work like that, the graduates not only ready in theory but also in practice prepared (Anshori, 2011). 
If the Link and Match program goes well, the government also benefited from the reduction in the burden of unemployment (educated personnel), because university graduates can be easily absorbed in the world of work (company) or even be able to create their own business (entrepreneurship).

\section{HIGHER EDUCATION CURRICULUM DEVELOPMENT}

The curriculum is described by Asmawi (2005) is a set of plans and arrangements regarding the content and study materials and lessons as well as the delivery and assessment are used as guidelines for the implementation of teaching and learning in higher education. The curriculum is divided into core curricula and local curricula (institutional). Curriculum core is part of the curriculum of higher education nationally applicable for each program of study, which includes educational objectives, content knowledge, and the ability of the minimum that must be achieved learners, in the completion of a program study. While local curricula (institutional) is part of the curriculum of higher education with regard to the circumstances and needs of the environment as well as the hallmark of the universities.

To develop the curriculum of higher education, universities are concerned based on national standards of education for each subject. The basic framework and structure of the higher education curriculum developed by the universities concerned by reference to national standards for each subject. (Article 38 paragraph 3 and 4 of Law No. 20 of 2003). Curriculum development prepared in accordance with the level of education within the framework of the Unitary State of the Republic of Indonesia with respect to: (Article 36 paragraph 3 of Law No. 20 of 2003)

1. Binding of faith and piety;

2. enhancement noble character;

3. enhancement potential, intelligence and interests of learners;

4. The diversity of the area and environmental potential;

5. Demands regional and national development;

6 . The demands of the world of work;

7. The development of science, technology and the arts;

8. Religion;

9. The dynamics of global development, and

10. National unity and national values.

Changes in education will not run without their curriculum to accommodate the changes that. Competency-based curriculum is an attempt to prepare learners have the intellectual ability, emotional, spiritual, and social quality is high. Competency developed survival skills and expertise in change, contradiction, uncertainty, uncertainty, and complexities in life (Muhtadi, 2007).

Curriculum is based on the principle of needs-oriented link and match concept. A healthy competitive in the world of education that begins with a curriculum that is proportional spawned human resources professional and accountable (Ditman, $\mathrm{tt}$ ).

Curriculum development at the College in order to link and match with the labor market or the business world can be done by referring to the opinion of Muhtadi (2007), using the approach (1) academic, (2) life skills (life skills), (3) 
competency-based curriculum (competency-based curriculum), (4) broad-based curriculum (broad-based curriculum).

\section{APPROACH IN THE MAKING LINK AND MATCH}

Several approaches are necessary in realizing the link and match between the world of education with the world of work. Here Anshori (2011) split in the form of labor and social approach.

Social approach

Social approach is an approach that focuses on the goals of education and on equal access to education (Usman, 2006) social approach will be a traditional approach to the development of education by providing institutions and facilities to meet the pressure of the pressure to enter the school as well as enabling provision of opportunity for student and parents freely (Indar, 1995) .For example of this approach is the implementation of a policy of double through Link and Match.

Some flaws in this approach: (Sa'ud in Anshori, 2011)

1. Ignore the allocation problem on a national scale, and vaguely not concerned about the level of resources necessary education, because they thought that the best use of education resources is to all the people of Indonesia;

2. Ignoring the need of labor (man power planning) is needed in the community so as to produce graduates who are actually not needed by the community;

3. Tend just answered distribution of educational course that quantity takes precedence over the quality.

\section{a. Employment approach}

Labor approach is an approach to educational activities directed to the effort to meet the national demand for labor. In the early stages of development of course requires a lot of manpower at all levels and in various types expert. In these circumstances most countries are expecting in order to prepare education and produce skilled manpower for development, whether in agriculture, trade, industry and so on (Enoch in Anshori, 2011) .For the educational planners must try to make an estimate of the quantity and quality of labor required by each national development activities.

Required methods to estimate workforce needs in accordance with the interests and conditions of employment. Approach is often used by countries that have developed or technologically advanced country, where every time a new kind of expertise required. Expert modern technology to create a theory and a new system by itself push technology to develop rapidly and this has also caused the emergence of the need for experts from new types to handle or manage them.

Countries that use the approach of employment (man power approach) directs the activities of education on a regular basis to businesses to meet the demands of the world of employment in all field. Economics expect that there is a balance between additional employment increased national revenue. The addition of jobs will increase national income, national income has been upgraded will provide opportunities to expand employment. This means that employment will be more. 
Theoretically this approach prefers linkages with the educational system graduates will demand labor needs. Some of the drawbacks presented by Usman (2006) in this approach are:

1. Has a limited role in education planning, because this approach ignores the existence of public schools because it will result in unemployment, this approach is more priority to vocational schools to meet the needs of the workplace;

2. Using the classification ratio of demand and supply;

3. The purpose of this approach is simply to fulfillment labor requirements, on the other hand the demands of a changing world of work in accordance with the rapidly changing times.

Meanwhile, it was realized that without the development of skilled labor, and skilled employment in accordance with the national development may not be able to walk with fluently. However in reality there are many obstacles in business planning approach education with employment, particularly in developing countries such as Indonesia (Anshori, 2011. Some key constraint among others: (Enoch in Anshori, 2011)

1. The availability of data and sufficient information to be able to answer questions with respect to how many jobs there after his kind; how the amount of labor that can be absorbed by education; how the business development / employment in the future and how the projections of labor that will be required; etc;

2. Requires data and projected workforce needs in the future, require clear requirements regarding power quality demanded by the labor market or educational institution graduate qualification requirement is for each type of employment;

3. Even in case of data and information on employment provided adequately, but those barriers will still exist, especially in the procurement of labor itself through formal education. The main cause is the inability of the national education system to make adjustments with various needs skills and abilities of its graduates.

\section{b. Academic approach}

The curriculum is an educational device, which must be prepared in accordance with the rules of science or based on theories that evolve with the development of science. Some of the rules of the academic curriculum development, among others: (Muhtadi, 2007)

1. The curriculum contains a draft education and training of a comprehensive and integrated.

2. The curriculum contains components of interest, content or materials and evaluation that are designed into a coherent whole.

3. The purpose of the curriculum has clearly indicated that direct destinations (instructional effect) and indirectly as a result of interest Bridesmaids (nurturant effect) for the development of learners completely.

\section{c. Life Skills Approach (Life Skills)}

So that students can become familiar with his world and be able to live decently in society, need to learn life skills (life skills). Life skills include: (1) skill to know oneself (self awareness) and rational thinking skills (thinking 
skills); (2) social skills (social skills); (3) academic skills (academic skills), and

(4) vocational skills (vocational skills).

\section{d. Approach Competency Based Curriculum (Competency-based Curriculum)}

Competence is the ability of a person who is required to complete a specific job in the world of work and official recognition of these capabilities, which are described Muhtadi (2007) as follows:

1. Competency-based curriculum is defined as education and training plans developed based on the requirements of the applicable standards of competence in the workplace.

2. Substance of competence include a statement of knowledge (knowledge), skills (skills) and attitude (attitude).

3. Fill or curriculum materials designed with competency based approach organized with modular system (whole unit), arranged sequentially and systemic. The modular design of the system is substantially based on units of learning competence as a whole, so as to facilitate the transfer of a unit of study to other study unit is based on the principle of learning thoroughly. In practice, the material can be shaped to support learning module.

4. There is a direct correlation between the levels of job positions in the world of work by phasing the achievement of competence.

Competency-Based Curriculum (KBK) is Salu curriculum model that was developed and applied to vocational education (Muhtadi, 2007) .KBK can also be applied in the College with regard to labor market needs or the business world, so that learners are able to reflect on his ability to apply in working world.

The concepts in the approach of competence based on two basic philosophies expressed Blank (in Muhtadi, 2007), namely (1) human competence, an ability that actually looks, knowledge, behavior and effort is worthless without result; and (2) mastery learning, that almost anyone can learn all knowledge well, if getting quality teaching and sufficient time.

\section{e. Broad-based curriculum approach and Fundamental (Broad-based Curriculum)}

Learners not only understand and master what (know what) and how (know how) a job done, but it must come to an understanding and mastery of why (know why) do. Thus, Muhtadi (2007) states that the curriculum is not only developed for the purpose of mastery of a competence in the strict sense, but is directed to the mastery of competencies in a broad sense, including the competence to adapt or assign / transfer competencies held to the new situation.

The competencies of broad-based or can be said to be comprehensive is needed for curriculum development in universities, so the students are not only able to master the theory, but proficient in jobs which they are responsible in the world of work in accordance with the development of science and technology is developing very fast. Access to information can be obtained easily and inexpensively, anytime and anywhere, so by doing the good cooperation between the College as a constituent of the curriculum with the students who completed their education based on curriculum, will be able to produce learners who qualified, can fill in the job market and can compete in accordance with its competence. 


\section{COMPREHENSIVE REVIEW of HIGHER EDUCATION CURRICULUM DEVELOPMENT}

Curriculum planning is the first step in the process of curriculum development. Finch \& Crunkilton (1984), describes the stages in curriculum development in technology and vocational education. One approach used in planning the curriculum known as the systems approach, which is described as follows:

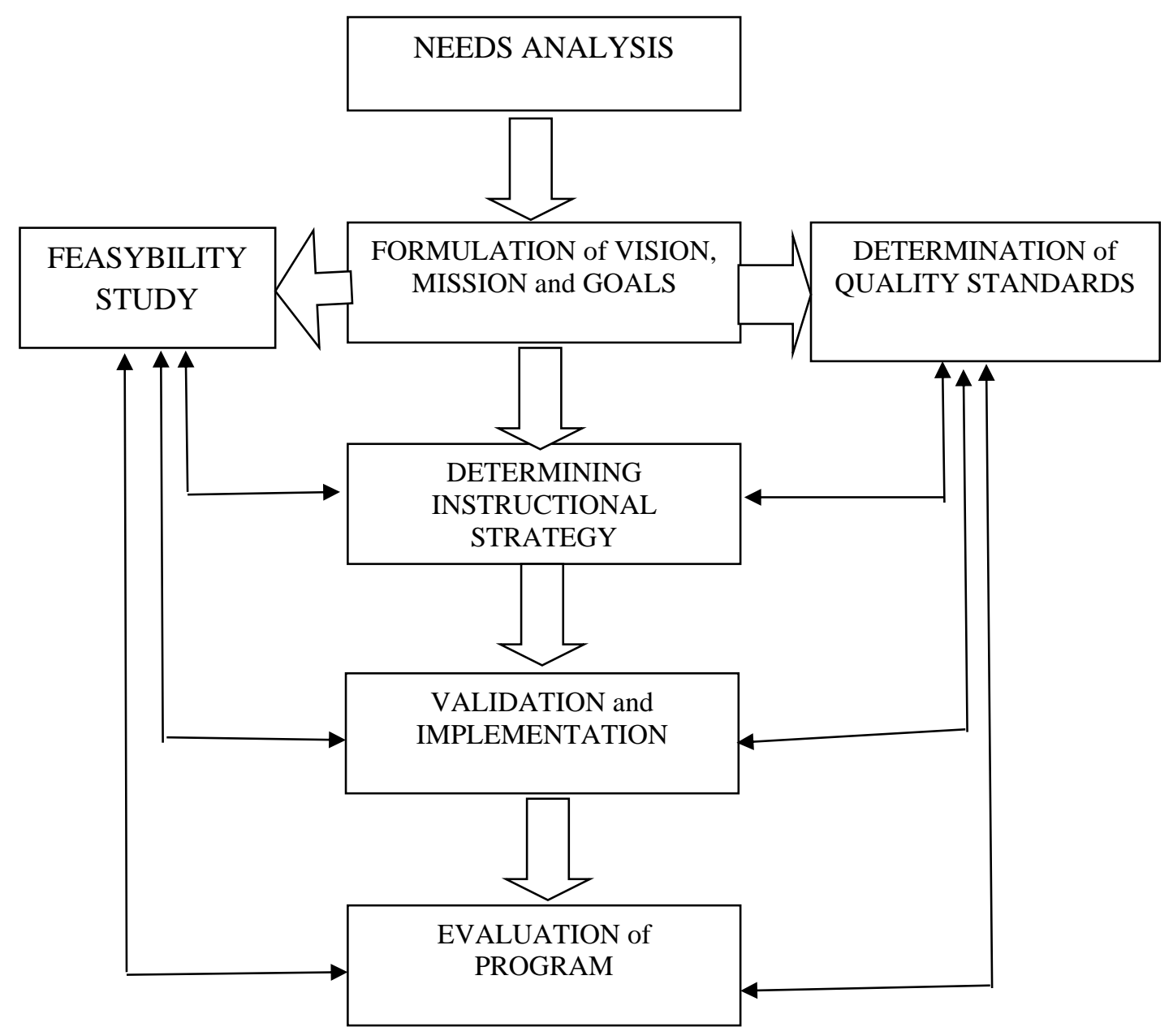

Figure 1.

Systems Approach in

Planning and Curriculum Development

(Source: Muhtadi, 2007) 


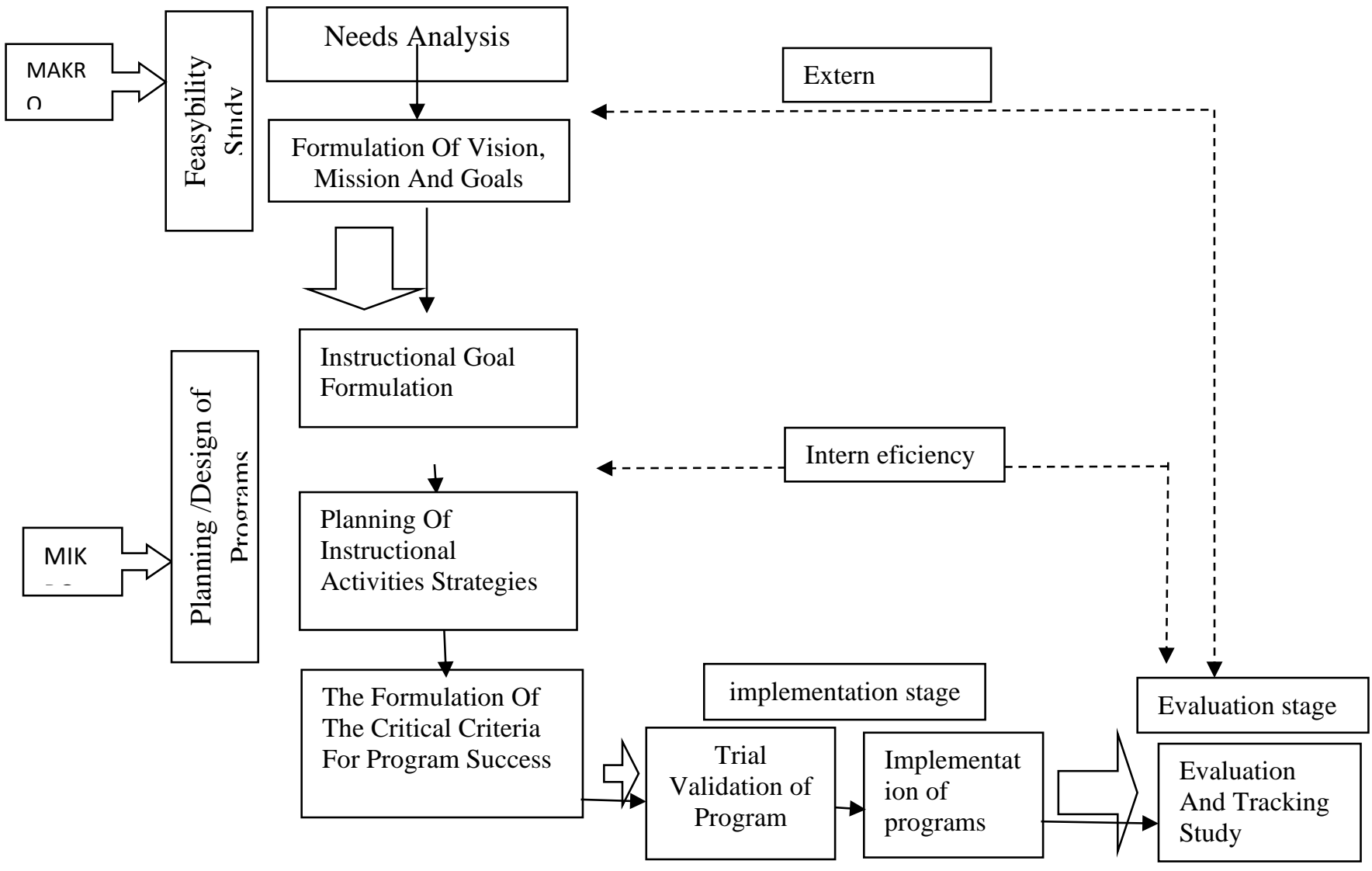

Figure 2.

Conceptual Framework and Operational planning Curriculum

(Source: Muhtadi, 2007)

College curriculum development can be done with reference to the Muhtadi (2007) through several stages, namely (1) curriculum planning; and (2) the determination of the content of the curriculum.

\section{Curriculum Planning}

1. Process determination

2. Decision making

3. Assess and collect data related to schools

4. Assess and collect data related to the community
Determining The Contents of The Curriculum

1. - using strategy to define contents

2. Decision makaing about curriculum contents

3. -develop the general goals and objectives of the curriculum

Figure 3.
Implementation of curriculum 


\section{DETERMINATION OF HIGHER EDUCATION CURRICULUM CONTENT.}

Finch \& Crunkilton (1984) suggested some strategies / approaches that can be used in identifying the content of the curriculum, are:

1. Philosophical Approach, that (a) the determination of the content of the curriculum subjective; (B) it is difficult to find agreement among experts with curriculum planners; $(\mathrm{C})$ is part of the partial and contradictory.

2. Approach Introspective, that (a) the determination of the content of the curriculum by a group of teachers and administrators; (B) the results are not guaranteed valid curriculum in accordance with the world of work; (C) the need to involve the business world and the industrial world in the curriculum advisory committee.

3. DACUM approach, that (a) the determination of the content of the curriculum is dominated by the business world and the industrial world; (B) teachers and administrators are less able to make a positive contribution in the determination of the content of the curriculum; (C) the results of the curriculum until the appropriate competence to real work situations; (D) the orientation of the commission or the participants about the planned program and what his expectations; (E) review job descriptions and tasks in real situations; $(\mathrm{F})$ identify the categorization of general competence in the field of employment; (G) identify a set of specific competencies in the category of general competence intangible $\mathrm{K}, \mathrm{S}, \mathrm{A}$.; $(\mathrm{H})$ organizing competencies in order to be translated into a sequence of learning (psychological principles of learning); (I) determining the level of competence as a benchmark assessment of learning outcomes.

4. Functional Approach, that (a) the determination of the content of the curriculum is more objective; (B) the function of industrial work translated into performance associated with a particular function to be used as input for curriculum planners; (C) the process of determining the content of the curriculum requires a lot of cost and time.

5. Analysis Approach Task (Task Analysis), that (a) analysis conducted on workers in the industry (job incumbent); (B) the determination of the content of the curriculum is more objective; (C) determining the curriculum content in a more systematic, thorough or careful; (D) it takes a very long time, the cost of research and development is very expensive.

\section{RELEVANCE OF HIGHER EDUCATION WITH THE BUSINESS WORLD}

The relevance of higher education is the relevance of higher education to play its role (education, research, and service) in the community, as well as its association with the world of work in the broad sense; association with the government; and interaction with various levels and types of education. To maintain relevance High education need to develop a Synergistic University Networking that will interact (Dirman, tt), namely by:

1. Government;

2. The business world and industry / private sector;

3. Type and other levels of the education system; 
4. Culture and culture;

5. The interests of each person;

6. Every place and time;

7. Students and lecturers

Problems will arise whenever relevance when there is a change from one situation to another different or changing rapidly, or if forces in society of mutual attraction. Such conditions at the time this has happened with the information and communication technology revolution that has transformed the world into a global society with all the effects and needs. In such circumstances, higher education should be able to play a fundamental role by putting all its resources as well as the spirit of freedom of certain attachments in serving what is relevant to humanity and society in general.

Globalization of the world economy, an increase in operations of multinational companies, as well as its impact, the modernization of the production process of goods and services, all really require advanced technology. Therefore, higher education must always prepare the curriculum in order to establish cooperation with business and industry, particularly in life-long training and higher education curricula education. Thus should lead to the principle of lifelong learning (Dirman, $\mathrm{tt}$ ).

One important result of contact world of higher education and business / industry (Dirman (tt) the entrepreneur spirit is awakening in higher education, including the teaching of efficiency, effectiveness, as well as feelings of competition and the need for skills in the competition for students. Instead of higher education to contribute to the business / industry in the use of research results as well as the multiplier effect of the results of the research for the universality of the development of a more harmonious world.

The business world has been accustomed to adapting to changes in the market, while the world of higher education should also have the sensitivity. That kind of cooperation is therefore required that universities can adapt without losing its distinctive identity as well as other priorities in anticipation of the long-term needs the public. Neverthels, one of the main obstacles facing the development of common curriculum is how to actuality into flexible of curriculum. Commonly the developers of the curriculum in higher education too often add knowledge / new teaching materials in its curriculum. While knowledge itself developed and developing very quickly so that the material that will be obsolete. Therefore, the emphasis of education must be replaced from the paradigm of transmission of knowledge into a process for generating knowledge which was later called Teaching How to Learn (Dirman, $\mathrm{tt}$ ).

Higher education must be proactive to the development of the labor market by analyzing, predicting, and preparing the emergence of employment forms and the required new forms. Research collaboration with the business world and the business world of industry. Coorporation with both large and small scale needed and directed to provide basic training for students and ongoing training of employees who continue their education. It should also be cooperation in organizing training courses, cost sharing for certain types of training, link-work and training, the use of mutually beneficial both in terms of human resources and facilities, as well as technology transfer developed within the framework of the 
cooperation. Meanwhile, to prepare graduates entering the labor market, higher education should be able to develop Business Incubator Enterprises with the support of the government, local communities, and the existing productive sectors.

9. CONCLUSION

1. The high intellectual unemployment because many college graduates are not absorbed by the labor market due to the graduates are not ready to work. This gap has not caused the education link and match with the corporate world.

2. The Government seeks to synergize the national education system with the system of employment in developing competency-based curriculum in accordance with the needs of the business community and the labor market. With this synergy, is expected to produce quality graduates or job seekers to meet the qualifications and requirements needed for entrepreneurship in business or independently

3. The concept of link and match between universities and the business world can be realized through labor and social approach. While the development of the curriculum in higher education can be done through (1) the academic, (2) life skills (life skills), (3) competency-based curricula (competency-based curriculum), (4) the curriculum of broad-based (broad-based curriculum).

\section{REFERENSI}

Amanahme. 2011. Aplikasi TP Dalam Peningkatan Keserasian Pendidikan. http://amanahtp.wordpress.com/2011/10/10/aplikasi-tp-dalam-peningkatankeserasian-pendidikan/.

Anomin.2011. Wamendikbud Musliar Mau Ubah Arah Kurikulum Perguruan Tinggi Siapkan Lulusan Sarjana yang Siap kerja. http://ekbis.rakyat merdeka online.com/

Anshori, Nunung Isa. 2011. Konsep Link and Match: Fungsi Pendidikan Sebagai Pemasok Tenaga Kerja Siap Pakai. http://www.asrori.com/2011/04/contohmakalah-pendidikan.html.

Ardiansyah, Asrori. http://elementary-education-schools.blogspot.com/2011/08/allabout-elementary-education-in.html.

Asmawi, M. Rosul. 2005. Strategi Meningkatkan Lulusan Bermutu di Perguruan Tinggi.Makara, Sosial Humaniora. Vol.9, No. 2, Desember: 66-71.

Damanhuri, Didin S. //www.sinarharapan.co.id/berita/0306/13/opi01.html.

Dirman. Tt. Pendidikan Untuk Hidup Berorientasi Pada Link And Match.

Farihin, Hamzah. 2011. Kurikulum PT Belum Sesuai Kebutuhan Dunia Usaha.http://www.uinjkt.ac.id/index.php/section-blog/1-headline/1892kurikulum-pt-belum-sesuai-kebutuhan-dunia-usaha.html.

Finch Curtis.R and Crunkilton. 1984. Curriculum Development In Vocational And Technical Education: Planning, Content, and Implementation. Sidney. Allyn and Bacon Inc.

http://edukasi.kompasiana.com/2011/03/28/dies-natalis-ke-51-fakultas-ekonomikurikulum-pt-harus-berbasis-pasar-kerja/: Kurikulum PT Harus Berbasis Pasar Tenaga Kerja. 2011. 
http://edukasi.kompasiana.com/2012/01/04/jembatan-yang-koyakketidaksinambungan-dunia-pendidikan-dan-dunia-kerja/. Jembatan yang Koyak: Ketidaksinambungan Dunia Pendidikan dan Dunia Kerja. 2012.

http://www.bunghatta.ac.id/berita-50-kurikulum-berbasis-kompetensi-tak-jelas.html. Kurikulum Berbasis Kompetensi Tak Jelas. 2005.

http://www.dpp.pkb.or.id/index.php?option=com_content\&view=article\&id=1636:p emerintah-akan-kembangkan-kurikulum-berbasis-kompetensi \& catid=44: berita-nasional \& Itemid $=118$. Pemerintah akan kembangkan kurikulum berbasis kompetensi.

http://www.duniaesai.com/index.php?option=com_content\&view=article\&id=108:sd m-indonesia-dalam-persaingan-lobal\&catid=37:ekonomi\&Itemid=93.SDM Indonesia dalam Persaingan Global.

http://www.indopos.co.id/index.php/arsip-berita-nasional/34-berita-nasional/16825belum-link-and-match-ubah-kurikulum-pendidikan.html. Belum Link and Match, Ubah Kurikulum Pendidikan. 2011.

http://www.jpnn.com/read/2011/10/25/106605/Sebelum-Lulus-Mahasiswa-WajibMagang-. Sebelum Lulus Mahasiswa Wajib Magang.2011.

Indar, Djumberansyah. 1995. Perencanaan Pendidikan Strategi dan Implementasinya. Surabaya: Karya Aditama.

Kuswara, Heri. herikuswara[at]gmail.com.

Muhtadi, Ali. 2007. Telaah Pengembangan Kurikulum Kompetensi pada Pendidikan Teknologi dan Kejuruan.FIP.UNY.

Munib, Achmad. 2009. Pengantar Ilmu Pendidikan. Semarang: Unnes Press

Suyitno, 2015. Education Innovation Efforts In Improving Teacher Competency In Tulungagung, East Java, Konstruktivisme: Jurnal Pendidikan \& Pembelajaran Jilid 7 No 2 hal. 76-84 konstruktivisme.unisbablitar.ejournal.web.id

Suyitno, 2016. Leadership Strategy To Enhance Islamic Education Quality: A Single

Case Study at Darush-sholihin Boarding Schools in Nganjuk, East Java, Indonesia. https://doi.org/10.25255/jss.2016.5.2.165.171

Suyitno, 2017. Strategi Kepala Sekolah Dalam Peningkatan Prestasi Belajar Siswa (Studi Kasus Di SMPN 1 Fakfak). Konstruktivisme: Jurnal Pendidikan \& Pembelajaran Jilid 9 No 1 hal. 39-56 konstruktivisme.unisbablitar.ejournal.web.id

Tola, Burhanuddin. Roadmap Penelitian Kebijakan dan Pengembangan Pendidikan. Pusat Penelitian Kebijakan dan Inovasi Pendidikan. Badan penelitian dan Pengembangan Kemendiknas. 